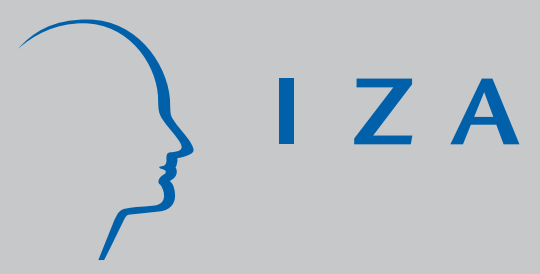

IZA DP No. 4111

Do Immigrants Take the J obs of Native Workers?

Nikolaj Malchow-Møller

J akob Roland Munch

J an Rose Skaksen

April 2009 


\title{
Do Immigrants Take the Jobs of Native Workers?
}

\author{
Nikolaj Malchow-Møller \\ CEBR and University of Southern Denmark \\ Jakob Roland Munch \\ University of Copenhagen, CEBR and EPRU \\ Jan Rose Skaksen \\ Copenhagen Business School, CEBR and IZA
}

\section{Discussion Paper No. 4111 \\ April 2009}

\author{
IZA \\ P.O. Box 7240 \\ 53072 Bonn \\ Germany \\ Phone: +49-228-3894-0 \\ Fax: +49-228-3894-180 \\ E-mail: iza@iza.org
}

\begin{abstract}
Any opinions expressed here are those of the author(s) and not those of IZA. Research published in this series may include views on policy, but the institute itself takes no institutional policy positions.

The Institute for the Study of Labor (IZA) in Bonn is a local and virtual international research center and a place of communication between science, politics and business. IZA is an independent nonprofit organization supported by Deutsche Post Foundation. The center is associated with the University of Bonn and offers a stimulating research environment through its international network, workshops and conferences, data service, project support, research visits and doctoral program. IZA engages in (i) original and internationally competitive research in all fields of labor economics, (ii) development of policy concepts, and (iii) dissemination of research results and concepts to the interested public.
\end{abstract}

IZA Discussion Papers often represent preliminary work and are circulated to encourage discussion. Citation of such a paper should account for its provisional character. A revised version may be available directly from the author. 


\section{ABSTRACT}

\section{Do Immigrants Take the Jobs of Native Workers?*}

In this paper, we focus on the short-run adjustments taking place at the workplace level when immigrants are employed. Specifically, we analyse whether individual native workers are replaced or displaced by the employment of immigrants within the same narrowly defined occupations at the workplace. For this purpose, we estimate a competing risks duration model for job spells of native workers that distinguishes between job-to-job and job-tounemployment transitions. In general, we do not find any signs of native workers being displaced by immigrants. Furthermore, we find only very limited signs of replacement of native workers by immigrants. Instead, in particular low-skilled native workers are less likely to lose or leave their jobs when the firms hire immigrants.

JEL Classification: $\quad$ F22, J61, J63

Keywords: immigration, adjustment costs, displacement, job spells, duration model

Corresponding author:

Jan Rose Skaksen

Department of Economics

Copenhagen Business School

Porcelænshaven 16A

2000 Frederiksberg

Denmark

E-mail: jrs.eco@cbs.dk

\footnotetext{
* This paper is part of a joint project between CEBR and the Rockwool Foundation Research Unit. Financial support from the Rockwool Foundation is gratefully acknowledged. The authors wish to thank Anna Piil Damm, Christian Dustmann, Bent Jensen, Peder J. Pedersen, Michael Svarer, Torben Tranæs and participants at ETSG 2007 for many useful comments and suggestions. Vibeke Borchsenius and Jonas Helth Lønborg have provided excellent research assistance.
} 


\section{Introduction}

How does immigration affect the employment of native workers? There are numerous studies in the literature seeking to answer this question and most studies find that if immigration has any effects on native workers, these effects are quite small; see, e.g., Longhi et al. (2006). This seems to be in stark contrast to the popular perceptions in destination countries where there are widespread fears that immigrants take the jobs of native workers; see Malchow-Møller et al. (2008a). One possible explanation behind this apparent paradox is that the focus in the empirical literature has been on the aggregate consequences of immigration, while the perceptions of people are based on the actual experiences of those individuals who have worked where the immigrants have been employed. These effects may be hard to spot in the aggregate statistics.

In this paper, we therefore consider the employment consequences at the most disaggregate level by analysing the employment experience of native individuals working in the firms and occupations in which the immigrants are employed. More specifically, we ask the following question: Are there any signs at the firm level of native workers being replaced or even displaced by immigrants? ${ }^{1}$ Or are the immigrants simply hired (and fired) together with the native workers; a situation we may refer to as "joint placement"? To answer these questions, we estimate the short-run relationship between the employment of immigrants at the workplace and the individual job-separation probabilities of native workers employed within the same narrowly defined occupations. These probabilities will most closely reflect the individually perceived threats of being replaced or displaced when the firms hire immigrants. To the best of our knowledge, this is a novel approach in the analysis of employment effects of immigration.

The literature on job turnover at the individual level suggests that it is important to control for socio-economic characteristics such as gender and education; see, e.g., Royalty (1998). Furthermore, it is well known that job-separation rates decline with time on the job due to the accumulation of firm specific human capital; see Farber (1999) for an overview. For these reasons, we follow, e.g., Battu et al. (2008), Geishecker (2008), Munch et al. (2008) and Royalty (1998) and apply a duration model that controls for observed as well as unobserved individual heterogeneity, and allows for flexible duration dependence in the job-separation probabilities.

\footnotetext{
${ }^{1}$ As explained below, we think of displacement as situations where native workers are fired when immigrants are hired, whereas replacement is when immigrants are hired to replace native workers who have left their jobs.
} 
In the literature on the employment consequences of immigration, the focus has been on the net employment consequences for a group of individuals (typically regions or industries) when there is an increase in the supply of immigrant workers. Examples of such analyses are Borjas et al. (1997) and Card (2001), both using U.S. data, Dustmann et al. (2005), using U.K. data, Pischke and Velling (1997), using German data, and Angrist and Kugler (2003), using EU data. There is substantial variation in the results from these analyses but the general conclusion seems to be that immigration has very small negative employment implications for native workers; see Longhi et al. (2006) for an overview.

Since these studies consider the net employment implications for natives at the region or industry level, they may not capture short-run replacement and displacement effects at the individual level and hence not whether immigrants "take the jobs" of native workers. As a consequence, these analyses may understate the costs of immigration because even reallocations that do not lead to a net decline in employment of natives as a group may be associated with adjustment costs for the individual native workers if they have to find alternative employment or are temporarily pushed into unemployment; see, e.g., Klein et al. (2003). Furthermore, it is clear that from the individual perspective, costs related to displacement may be substantial; see, e.g., Farber (2005), Bender et al. (2002), and Borland et al. (2002). Job loss is associated with lower re-employment earnings, long spells of unemployment for some workers, and a higher probability of being part-time employed when re-employed (Farber, 2005).

Our focus is exactly the individual consequences of the adjustments taking place at the firm level when immigrants are hired. For this purpose, we use a very detailed linked employer-employee data set for the Danish labour market for the period 1993-2004. Job spells for native workers as well as workplace measures of immigrant employment are constructed from these data. Note that 19932004 is a period with a large inflow of immigrants into the Danish economy. In our data, the employment share for immigrants thus increased from 3.0 percent in 1993 to 5.2 percent in 2004, which constitutes one of the most pronounced relative increases in immigration among developed countries in recent years. 
To analyse whether individual native workers are replaced or displaced by immigrants, we estimate a competing risks duration model for job spells of native workers using various measures of immigrant employment within the same occupation and workplace as explanatory variables. The competing risks model allows us to distinguish between job-to-job transitions and job-tounemployment transitions of native workers. This is relevant as the latter transitions are both more likely to reflect displacements and to be associated with higher adjustment costs.

The model controls for both observed and unobserved individual heterogeneity and allows for flexible duration dependence in the transition process out of the current job. As we wish to eliminate any effects resulting from, e.g., workers with less stable employment patterns selfselecting into workplaces with immigrant employment, we also extend the basic duration model with selection equations for the workplace immigrant variables. Furthermore, to isolate any displacement or replacement effects from the effects of joint placement of natives and immigrants at growing (or shrinking) workplaces, we also control for various measures of job growth at the workplace level. Finally, as low-skilled native workers are often hypothesised to suffer more from immigration, we estimate separate effects for different educational groups of native workers.

In general, we find no signs of natives being displaced when firms hire immigrants, and we only find weak signs of replacement. On the contrary, in particular low-skilled native workers are less likely to lose or leave their jobs when firms hire immigrants; a strong indication of joint placement of natives and immigrants. Only among the group of native workers with a further education does the hiring of immigrants give rise to an increase in the job-to-job separation probability. However, as this reflects that native workers move into other jobs and not into unemployment, the adjustment costs associated with this are likely to be limited.

The rest of the paper is organised as follows: In Section 2, we present the empirical hypotheses to be tested in the paper and Section 3 presents our data. In Section 4, we outline the empirical strategy and Section 5 contains the results. Finally, Section 6 concludes. An Appendix with a detailed specification of the econometric model as well as detailed estimation results is attached at the end. 


\section{Empirical Hypotheses}

The analysis in this paper focuses on the adjustments taking place at the workplace level when immigrants are hired. Specifically, we wish to test the following three hypotheses about the relationship between the employment of immigrants and native workers within the same occupation at a workplace:

(a) Displacement: Native workers are fired (or leave) when immigrants are hired.

(b) Replacement: Immigrants are used to replace native workers when these leave (voluntarily).

(c) Joint placement: Natives and immigrants are hired (and fired) jointly.

We are particularly interested in analysing whether there is evidence of one of the two first effects. ${ }^{2}$ We test this by analysing whether the individual job-separation probabilities of native workers increase when the number of immigrants employed at the same workplace within the same occupation increases. Note that both (a) and (b) reflect substitution of native workers with immigrants - i.e. immigrants "taking the jobs" of native workers - but that especially the first effect is likely to be associated with considerable adjustment costs for the native workers. Hence, we also try to distinguish between these effects in the empirical analysis. In Section 4, we explain the approach in more detail including how we intend to distinguish between the different hypotheses.

By focusing on native workers employed in both the same workplaces and occupations as those in which the immigrants are employed, we restrict attention to the group of native workers for whom it is most likely to identify any potential adjustment costs associated with the hiring of immigrants. Thus, if no adjustment costs can be identified for these workers, adjustment costs are unlikely to be important.

\section{Data}

We apply a very rich data set for the Danish labour market. From the Integrated Database of Labour Market Research (IDA), we hold annual information about labour market status and socioeconomic characteristics of all Danish residents in the period 1980-2004. For more details on the IDA data, see, e.g., Abowd and Kramarz (1999).

\footnotetext{
${ }^{2}$ Actually, there is also a fourth possibility, namely the absence of any relationship between the employment of immigrants and natives. We can, however, consider this as a limiting case of (c).
} 
From IDA we extract a 2.5\% sample of native workers for the years 1993-2004, as 1993 is the first year in which occupational codes are observed (see below). From the observed labour market status of an individual combined with information about the workplace identity in the years of employment, it is straightforward to construct individual job spells from successive years of employment at the same workplace. ${ }^{3}$ Job spells are flow sampled such that only spells starting in 1994 and later are included in the analysis. ${ }^{4}$ At the end of a job spell, we distinguish between transitions into new jobs and transitions into unemployment. The destination state for all spells that end before 2004 is known, and if job spells end with transitions into other states than a new job or unemployment (e.g. out of the labour force), or if spells are not completed by the end of 2004, they are treated as independently right-censored observations.

In the following, we restrict attention to job spells of full-time native workers between 18 and 65 years of age and employed in private sector workplaces with at least 10 employees in the first year of a job spell. Some descriptive statistics for the job spells in the sample are provided in Table 1. It is seen that more than 60 percent of the spells end in a job-to-job change while 5 percent end in unemployment.

\section{[Insert Table 1 around here]}

For each year within a job spell, we have observations on individual characteristics such as age, gender, marital status, education, region of residence and type of occupation. The latter follows from DISCO, the Danish version of the International Standard Classification of Occupations (ISCO-88) developed by the International Labour Office (ILO). DISCO classifies individual occupations into 372 different types and is available from 1993 and onwards.

Furthermore, as all individuals in IDA are linked to workplaces, the whole population of full-time employees aged 18-65 is used to construct a number of annual workplace characteristics which are

\footnotetext{
${ }^{3}$ Note that since a firm can have more than one workplace, we count it as a job change when a worker switches between two workplaces within the same firm.

${ }^{4}$ In the empirical analysis to follow, we use covariates measuring changes between two years, so spells starting in 1993 are not included.
} 
subsequently merged on to the individual job spell data. These characteristics include, among others, the number of employees and the share of workers with different types of education.

In particular, we construct workplace measures of the share of immigrants within different occupations. For this purpose, we use the 2-digit DISCO classification, which distinguishes between 27 different occupations. Immigrants are defined as individuals born outside Denmark with non-Danish parents. If there is no information about the parents and the individual is born outside Denmark, he/she is also classified as an immigrant.

Figure 1 shows that since 1993 - the beginning of our sample window - the share of immigrants in the population of employed workers in Denmark has increased markedly. The increase corresponds to a relative increase of almost 75 percent over the period 1993-2004. Moreover, as found in Malchow-Møller et al. (2008b), the wages of immigrants are significantly lower than the wages of native workers. Hence, if the productivity of immigrants is not too low compared to that of native workers, there has been both an incentive and an opportunity for firms to substitute native workers with immigrant workers. A priori, this lends support to the hypothesis that the employment of immigrants leads to displacement of native workers.

\section{[Insert Figure 1 around here]}

In the estimations below, we use the following three measures of immigrants in the occupation of native worker $i$ at workplace $w$ :

$$
\begin{aligned}
\operatorname{imm}_{i w t} & =\frac{I_{i w t}}{N_{i w t}+I_{i w t}} \\
\Delta i m m_{i w t} & =\frac{I_{i w t+1}-I_{i w t}}{N_{i w t}+I_{i w t}} \\
L \Delta i m m_{i w t} & =\frac{I_{i w t}-I_{i w t-1}}{N_{i w t-1}+I_{i w t-1}}
\end{aligned}
$$

where $I_{i w t}$ is the number of immigrants in the occupation of (native) worker $i$ at his/her workplace $w$ in year $t$, and $N_{i w t}$ is the number of native workers in this occupation. Thus, $i m m_{i w t}$ is the share of immigrants in the occupation of worker $i$ at workplace $w$ in year $t$, while $\Delta i m m_{i w t}$ and $L \Delta i m m_{i w t}$ are 
measures of the change and lagged change, respectively, in this share. The three immigrant variables in (1) are further discussed in the next section.

Finally, Table 2 displays summary statistics for the individual and workplace control variables included in the analysis. At the individual level, there is information about age, sex, marital status and education. Specifically, we work with three levels of education: Basic education, vocational education and further education. This classification of education levels relies on Danish educational codes. Further education basically corresponds to the two highest categories (5 and 6) in the International Classification of Education (ISCED), i.e. tertiary education. Vocational education is defined as the final stage of secondary education encompassing programmes that prepare students for direct entry into the labour market. Thus, persons with just high school or equivalent are included in the basic education category. Also three geographical dummies are included to distinguish between the capital (Copenhagen), 5 large cities (large city), and all other localities (small city). Information about years of labour market experience is also available. Finally, we include dummy variables for the nine occupations in the 1-digit DISCO classification.

\section{[Insert Table 2 around here]}

At the workplace level, there is information about the number of employees, the share of workers with basic and further education, respectively, as well as the share of female workers and workers aged 40 years or more. Finally, the three immigrant variables defined in (1) are used.

From Table 2 it follows that roughly $40 \%$ of the observations (one observation is a person-year) are from occupations with immigrant co-workers. It is seen that native workers in occupations with immigrants are more likely to have basic or further education, whereas workers without immigrant co-workers are more likely to have vocational education.

\section{Empirical Strategy}

The purpose of the empirical analysis is to search for signs of native workers losing jobs to immigrants, i.e. being replaced or displaced. Furthermore, we wish - to the extent possible - to 
distinguish between the two effects (replacement and displacement) as especially the latter is likely to be associated with considerable adjustment costs for native workers.

For this purpose, we use a competing risks duration model for job spells of native workers which estimates separate hazard functions for job-to-job transitions and job-to-unemployment transitions (Sueyoshi, 1992):

$$
\theta_{s}\left(t \mid x_{t}, z_{t}, v_{s}\right)=\lambda_{s}(t) \cdot \exp \left(\beta_{s} x_{t}+\gamma_{s} z_{t}+v_{s}\right), \quad s=e, u
$$

where the subscript $s$ is used to distinguish between the two different destination states for the transition: employment $(s=e)$ and unemployment $(s=u)$. $\lambda_{s}(t)$ is the baseline hazard capturing the time dependence for transitions into destination $s$. That way we handle the stylized fact that jobseparation rates typically decline with time on the job due to the accumulation of match-specific human capital; see, e.g., Farber (1999). $\exp \left(\beta_{s} x_{t}+\gamma_{s} z_{t}+v_{s}\right)$ is the systematic part giving the proportional effects of the immigrant variables at the occupational level from (1), $z_{t}$, other observed time-varying individual and workplace characteristics, $x_{t}$, and an unobserved individual effect, $v_{s}$, which is time invariant but allowed to differ across the two destination states. Controlling for unobserved heterogeneity is relevant as no measures for, e.g., ability and motivation are available.

The hazard function thus gives the probability of leaving the job to a given destination state (unemployment or another job) in year $t$ given that the individual is still in the job at the beginning of year $t$. Note that all other destination states are treated as right-censored observations. A detailed specification of the competing risks model, including the baseline hazard, the unobservables distribution and derivation of the likelihood function, can be found in the Appendix.

As workplaces vary in size, we use the share of immigrants within an occupation, imm $_{i w t}$, as an explanatory variable in the hazard functions instead of the absolute number of immigrants. A problem with the $\mathrm{imm}_{\text {iwt }}$ variable, however, is that it does not only capture short-run effects of hiring immigrants. Thus, a positive effect of $\mathrm{imm}_{\text {iwt }}$ on the separation probability of natives may also reflect (i) a long-run effect on the separation probability of a workplace moving from a set-up with a low immigrant concentration to a set-up with a high immigrant concentration; and, more problematically, also (ii) cross-sectional differences between workplaces. The latter includes 
possibly unobserved workplace characteristics which affect the individual job-separation probabilities and which are correlated with the share of immigrants. For example, if immigrants are concentrated in firms with less job security, this may result in a positive coefficient to imm iwt $_{\text {which }}$ does not reflect any short-run adjustment effects. As a consequence, we do not wish to push the interpretation of the coefficient to $\mathrm{imm}_{\text {iwt }}$ too far. Instead, we prefer to think of it also as a proxy for unobserved workplace characteristics. ${ }^{5}$

Instead, to capture the short-run displacement and replacement effects, we use the change, $\Delta$ imm $_{\text {iwt }}$, and the lagged change, $L \Delta i m m_{i w t}$, in the immigrant share, defined as in (1). That is, we ask whether there is a relationship between an increase (or decrease) in the workplace use of immigrants (relative to the number of workers employed in that occupation) in the present or the previous period and the native job-separation probabilities in the current period. As an example, a positive coefficient to $\Delta \mathbf{i m m}_{i w t}$ in the job-to-job hazard function will imply that natives are more likely to leave for another job in the same period as more immigrants are employed within the same occupation at the workplace. This will indicate that native workers are, in fact, losing jobs to immigrants. However, we cannot see whether this happens before or after the immigrants are employed. Hence, it may reflect both replacement and displacement effects - and voluntary as well as involuntary separations.

In order to single out any displacement effects from the replacement effects, we can do two things. First, if we assume that displacements lead to unemployment whereas replacements result in another job, we can interpret a positive coefficient to $\Delta i m m_{i w t}$ in the job-to-unemployment hazard as a displacement effect, and a positive coefficient in the job-to-job hazard as a replacement effect.

It should be noted, however, that not all layoffs result in job-to-unemployment transitions. According to Browning et al. (2006), more than half of the displaced workers in the Danish labour market have no unemployment at all in the displacement year. Such transitions may still involve significant adjustment costs, in particular, if the worker takes a wage cut after a job change. The implication is that looking only at displacement via job-to-unemployment transitions will understate the amount of displacement. Still, however, job-to-unemployment transitions are informative about

\footnotetext{
${ }^{5}$ Similarly, unobserved worker characteristics which are correlated with the immigrant variables and determine individual job-separation rates may also affect the results. However, we deal explicitly with this possibility below.
} 
the most important adjustment costs for individual native workers, even when all displacements do not lead to unemployment.

The second possibility is to consider the estimated coefficients to $L \Delta i m m_{i w t}$, the change in the employment of immigrants last year. Positive coefficients to $L \Delta i m m_{i w t}$ in the job-to-unemployment and the job-to-job hazards will imply that native employees are more likely to become unemployed and switch to another job, respectively, in the year following an increase in the number of immigrants in the same occupation. As these events do not suffer from the timing problem above, positive coefficients can in both hazard functions be interpreted as evidence of displacement effects.

If, on the other hand, the coefficients to $\Delta i m m_{i w t}$ and $L \Delta i m m_{i w t}$ are negative, it means that native workers are less likely to leave the workplace when immigrants are employed. This indicates that firms are trying to keep their native workers when hiring immigrants, and less so when immigrants are fired/leave. We will take this as evidence of joint placement effects dominating any replacement or displacement effects.

If for some reason native workers with high (or low) separation probabilities tend to self-select into workplaces with high values of the immigrant variables, this may affect the estimated parameters. To eliminate this effect, we extend the basic duration model with selection equations for the three workplace immigrant variables. That is, we specify and estimate equations for $\mathbf{i m m}_{i w t}, \Delta i m m_{i w t}$, and $L \Delta i m m_{i w t}$ jointly with the hazard functions, and allow the unobserved individual effects in these equations to be correlated with the unobserved individual effects in the hazard functions. For example, for the change in the immigrant share, $\Delta i m m_{t}$, we specify the following selection equation:

$$
\Delta \operatorname{imm}_{t}=\beta_{m} x_{t}+\gamma_{m} y_{t}+u_{t}+v_{m},
$$

where $x_{t}$ are the explanatory variables from the duration model in (2), and $y_{t}$ are instrument variables that are included in the selection model in (3), but not in the duration model. For a given individual, the error term in (3) is composed of two components, an independently normally distributed idiosyncratic component, $u_{t}$, and a random individual-specific effect, $v_{m}$, which does not vary over time, but which is allowed to be correlated with $v_{e}$ and $v_{u}$ from (2). 
As instruments in the selection equations, we use the share of immigrants in the total employment in the local area as well as the changes in this variable in the current and the previous year. Further details of the specification of the selection equations are presented in the Appendix.

We also try to isolate any displacement or replacement effects from the effects of joint placement of natives and immigrants at growing (or shrinking) workplaces. This is done by controlling for job growth at the workplace level. That is, we ask: Can we find any signs of a higher use of immigrants being associated with higher separation rates of natives if we eliminate the correlation that is due to joint hirings/firings of natives and immigrants at expanding/contracting workplaces?

Finally, displacement effects may differ across educational groups. If, e.g., the degree of substitution between immigrants and native workers is higher among workers with basic skills than among workers with high skills, the hiring of immigrants should mainly affect native workers with basic skills. To study this issue, we interact the immigration variables with the individual education level.

\section{Results}

The first two columns of Table 3 present estimation results from the basic specification of the competing risks model without selection equations and controls for job growth included. Before we proceed to the impacts of the immigrant variables, we note that all model specifications include as controls the variables listed in Table 2. The effects of these variables are not shown in Table 3, but are contained in the Appendix tables. For example, we find negative duration dependence meaning that the probability of leaving a job (either to another job or to unemployment) decreases with the amount of years in the job. We also find that women and older individuals are less likely to switch jobs but more likely to become unemployed. Also workers with further education and more experienced workers are less likely to become unemployed. ${ }^{6}$

\section{[Insert Table 3 around here]}

\footnotetext{
${ }^{6}$ With respect to the unobserved heterogeneity, we find that the probability mass is concentrated at two points revealing a strong positive correlation between the unobserved effects in the two hazard functions; see Table A1 in the Appendix.
} 
With respect to the immigrant variables, we observe that the coefficients to $\Delta$ imm $_{\text {iwt }}$ are significantly negative in both hazard functions indicating that the hiring of immigrants is associated with a decrease in the probabilities of native workers becoming unemployed or changing job. The estimated effects suggest that an increase in $\Delta \mathbf{i m m}_{t}$ from, say, 0 to 0.1 , i.e. adding an extra immigrant in an occupation with 10 workers initially, lowers the job-to-job separation probability by $0.9 \%$ and the job-to-unemployment separation probability by $2.2 \%$, whereas adding an extra immigrant in an occupation with only two workers initially will lower the job-to-unemployment separation probability by more than $10 \%$.

The job-to-unemployment separation probability is also lowered in the period following the increased immigrant employment as indicated by the estimated coefficients to $L \Delta \mathbf{i m m}_{t}$. Finally, the stock of immigrants, as measured by the immigrant share, $\mathrm{imm}_{\mathrm{t}}$, is not found to be related to the jobseparation probabilities of native workers.

Eliminating the correlation due to self-selection of individuals (columns 3 and 4 in Table 3) has only little impact on the estimated coefficients. Thus, there are no signs that individuals with higher job-separation rates tend to self-select into workplaces with higher values of the immigrant variables. ${ }^{7}$ In the following estimations we therefore continue without the selection equations included as this reduces estimation time considerably.

Thus, taken together the results in Table 3 do not lend much support to the hypothesis that immigrants take the jobs of native workers. On the contrary, the fact that the estimated coefficients are negative indicates that joint placement of immigrants and natives dominate any displacement or replacement effects. One explanation for this may be that expanding workplaces hire immigrants together with native workers, and therefore also try to keep the currently employed native workers, while contracting workplaces fire the two groups of workers together. Thus, to investigate if we can

\footnotetext{
${ }^{7}$ Since many of the mass point probabilities in the full model with 32 mass points converged towards zero, we restricted the correlation structure between the three selection equations to be perfect. This still allows for a completely flexible correlation between the job-change hazard, the unemployment hazard and the selection equations. The estimated mass points and associated probabilities (see Table A2 in the Appendix) imply that the correlation coefficients between the job-change hazard and the selection equations and between the unemployment hazard and the selection equations are very low and insignificant (-0.0105 and -0.0156 , respectively). This explains why the bias from not accounting for selection is small.
} 
find any signs of displacement or replacement - i.e. where use of immigrants lead to higher separation rates of natives - we try to eliminate this effect by controlling for job growth at the workplace level.

Table 4 contains estimates where we have included measures of employment growth at the workplace in the previous period (columns 1 and 2) and in the present period (columns 3 and 4). ${ }^{8}$ We see that the growth rate in the previous period, job growth ${ }_{t-1}$, does not enter with significant coefficients in any of the hazard rates, and its inclusion does not affect the estimated parameter values for the immigration variables. In contrast, the present period growth rate, job growth ${ }_{t}$, has a strong negative correlation with both hazard rates, which supports the suggestion that expanding workplaces try harder to retain their current workers.

It should be stressed here that any causal interpretation of the coefficients to job growth $t$ is difficult because the workplace job growth between period $t$ and $t+1$ is almost mechanically (negatively) related to the probability of a job separation between period $t$ and $t+1$. Bearing this in mind, we also

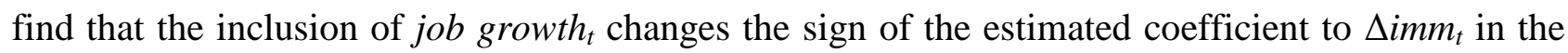
job-change hazard but not in the unemployment hazard. Thus, we still do not see any signs of direct displacement via job-to-unemployment transitions, but as discussed in the previous section, the positive parameter value in the job-change hazard may reflect displacement to some extent, if displaced native workers manage to get a new job without intermediate unemployment spells. However, if displacement is an important issue, it should also show up directly in the unemployment hazard. In any case, the estimated coefficient to $\Delta \mathbf{i m m}_{t}$ in the job-change hazard suggests that the employment of an extra immigrant in an occupation with 10 workers initially increases the job-to-job transition probability by $1.0 \%$, e.g., from $10 \%$ to $10.1 \%$, which is a very modest effect.

\section{[Insert Table 4 around here]}

In the above estimations, we have not allowed for different effects for different educational groups of native workers. If, e.g., the degree of substitution between immigrants and native workers is

\footnotetext{
${ }^{8}$ The job growth variables are defined as the growth rate in the number of employees at the workplace between $\mathrm{t}-1$ and $\mathrm{t}$ and between $t$ and $t+1$, respectively.
} 
higher among workers with basic skills than among workers with high skills, the hiring of immigrants should mainly give rise to displacement of native workers with basic skills. To study this issue, we interact the immigration variables with our three educational indicators for the native workers: basic education, vocational education and further education. The results are reported in the first two columns of Table 5. It is seen that the impact of hiring immigrants varies somewhat over the different educational groups. However, all the significant coefficients are negative except one: The employment of immigrants is associated with an increase in the job-change probability for native workers with further education in the following period. The estimated coefficient is, however, very small, suggesting that an increase in $L \Delta i m m_{t}$ from, e.g., 0 to 0.1 , is associated with an increase in the job-to-job separation probability of native workers with further education of $0.8 \%$. That is, if the job-to-job separation probability was initially $10 \%$, this increase in $L \Delta \mathbf{i m m}_{t}$ will raise it to $10.08 \%$. Again, this is a very modest effect, and as the hiring of immigrants does not lead to a higher risk of unemployment, it is likely to be associated with very limited adjustment costs.

\section{[Insert Table 5 around here]}

As a robustness check, we have also included measures of employment growth at the workplace in the previous period (columns 3 and 4) and in the present period (columns 5 and 6). The inclusion of previous period job growth leaves all coefficients almost unchanged, but controlling for present period job growth has an influence as in Table 4. Again, these results should be interpreted with caution because of the (mechanical) relationship between present period job growth and job separations. There are still no signs of direct displacement effects via job-to-unemployment transitions as all coefficients in the unemployment hazard are either insignificant or negative. It is, however, now only workers with basic education that experience a strictly lower unemployment risk when the workplace hires immigrants.

With respect to the job-change hazard, a positive relationship between the hiring of immigrants in the present period, $\Delta i m m_{t}$, and the job-to-job transition probability emerges when controlling for job growth $_{t}$. This is similar to what we found in Table 4 (column 3). However, Table 5 (column 5) reveals that this only applies to workers with vocational and, in particular, further education. As we expect displacement mostly to happen for low-skilled native workers, this further indicates that these coefficients are likely to reflect replacement rather than displacement effects. 
In sum, even when eliminating the effects of joint placement by controlling for job growth at the workplace level, it is difficult to find signs of any direct displacement effects. Only for educated workers can we detect a small positive effect on the job-to-job transition probability from hiring immigrants in the previous period. The size of this effect is, however, too small to have any practical relevance.

\section{Conclusion}

In this paper, we have focussed on the adjustments taking place at the workplace level when immigrants are employed by looking at the relationship between the job-separation probabilities of native workers and the increased use of immigrants within the same occupation at the workplace. Specifically, we have estimated a competing risks duration model for job spells of native workers that distinguished between job-to-job and job-to-unemployment transitions.

In general, we do not find any signs of native workers being actively displaced by immigrants. Furthermore, we find only very limited signs of replacement of native workers by immigrants - and these effects are only found for skilled workers. That is, we find that the job-to-job transition probabilities increase slightly for skilled workers when immigrants are employed within their occupation. Workers with only basic education are (if anything) positively influenced in terms of job security by the employment of immigrant co-workers.

Taken together, we can conclude that there is no evidence to support the popular perception that immigrants "take the jobs" of native workers - even when we look at the adjustments taking place at the most disaggregate level, i.e., in the occupations and workplaces in which the immigrants are employed. What drives this popular perception thus remains an unresolved puzzle. 


\section{Appendix A: The Econometric Model}

This appendix contains the details of the competing risks model used in the paper. We specify the mixed proportional hazard model for the two labour market transitions (job-to-job and job-tounemployment) as:

$$
\theta_{s}\left(t \mid x_{t}, z_{t}, v_{s}\right)=\lambda_{s}(t) \cdot \exp \left(\beta_{s} x_{t}+\gamma_{s} z_{t}+v_{s}\right), \quad s=e, u
$$

where the subscript $s$ is used to distinguish between the two different destination states for the transition: employment $(s=e)$ and unemployment $(s=u) . \lambda_{s}(t)$ is the baseline hazard capturing the time dependence for transitions into destination $s$, and $\exp \left(\beta_{s} x_{t}+\gamma_{s} z_{t}+v_{s}\right)$ is the systematic part giving the proportional effects of the immigrant variables, $z_{t}$, other observed time-varying individual and workplace characteristics, $x_{t}$, and an unobserved individual effect, $v_{s}$, which is time invariant but allowed to differ across the two destination states. The vector of immigrant variables, $z_{t}$, consists of the three measures from (1), where subscripts $i$ and $w$ are now suppressed to simplify notation: $z_{t}=\left\{i m m_{t}, \Delta i m m_{t}, L \Delta i m m_{t}\right\}$. All job spells that end with a transition to another state than one of the two described above (e.g., out of the labour force) are treated as independent rightcensored observations.

The annual nature of the data imply that the duration variable, $T$, is grouped into $K+1$ intervals $\left\{\left[0, t_{1}\right),\left[t_{1}, t_{2}\right), \ldots,\left[t_{K}, \infty\right)\right\}$, which must be accounted for in the econometric specification. Thus, following Kiefer (1990), the interval specific survival rate is defined as

$$
\begin{aligned}
\alpha_{k} & =P\left(T \geq t_{k} \mid T \geq t_{k-1}, x_{k}, z_{k}, v\right) \\
& =\exp \left[-\sum_{s=e, u} \int_{t_{k-1}}^{t_{k}} \theta_{i}\left(t \mid x_{k}, z_{k}, v_{s}\right) d t\right] \\
& =\exp \left[-\sum_{s=e, u} \exp \left(\beta_{s} x_{k}+\gamma_{s} z_{k}+v_{s}\right) \Lambda_{s, k}\right] \\
& =\prod_{s=e, u} \alpha_{s, k}
\end{aligned}
$$

where $\Lambda_{s, k}=\int_{t_{k-1}}^{t_{k}} \lambda_{s}(t) d t$ and $\alpha_{s, k}=\exp \left[-\exp \left(\beta_{s} x_{k}+\gamma_{s} z_{k}+v_{s}\right) \Lambda_{s, k}\right]$. 
To find the contribution to the likelihood function from a job spell, it is noted that the probability that a spell ends in interval $k$ is given by the conditional probability of failure in that interval times the probability that the spell survives until interval $k$, i.e. $\left(1-\alpha_{k}\right) \prod_{j=1}^{k-1} \alpha_{j}$. Right-censored spells contribute to the likelihood with the survivor function, $\prod_{j=1}^{k} \alpha_{j}$, and so the contribution to the likelihood function from a job spell ending in interval $k$ can be written as:

$$
L_{e u}\left(t \mid x_{1}, \ldots, x_{k}, z_{1}, \ldots, z_{k}, v_{e}, v_{u}\right)=\left(1-\alpha_{e, k}\right)^{d_{e}}\left(1-\alpha_{u, k}\right)^{d_{u}} \alpha_{k}^{1-d_{e}-d_{u}} \prod_{j=1}^{k-1} \alpha_{j}
$$

where $d_{e}$ and $d_{u}$ are destination state indicators. If the job spell is right censored then $d_{e}=d_{u}=0$. Instead of imposing a functional form on the baseline hazard, we allow for a flexible specification by simply estimating the interval specific baseline parameters, $\Lambda_{s, k}$.

To eliminate any bias arising from $v_{e}$ and $v_{u}$ being correlated with $z_{t}, e . g$., because workers with unstable employment patterns select into firms with high shares of immigrants and/or large changes in these, we model the variables in $z_{t}$ simultaneously with the transition rate out of a job spell. For example, for the change in the immigrant share, $\Delta i m m_{t}$, we specify the following selection equation:

$$
\Delta \operatorname{imm}_{t}=\beta_{m} x_{t}+\gamma_{m} y_{t}+\varepsilon_{t}
$$

where $x_{t}$ are the explanatory variables from the duration model in (A1), and $y_{t}$ are instrument variables that are included in the selection model in (A4), but not in the duration model. Note that the subscript " $m$ " on the parameters indicates that these belong to the selection model, whereas subscripts " $e$ " and " $u$ " are used in the duration model. For a given individual, the error term in (A4) is composed of two components, an independently normally distributed idiosyncratic component, $u_{t}$, and a random individual-specific effect, $v_{m}$, which does not vary over time:

$$
\varepsilon_{t}=u_{t}+v_{m}
$$

The likelihood contribution from a sequence of changes in immigrant shares over a job spell is thus 


$$
L_{m}\left(\Delta i m m_{1}, \ldots, \Delta i m m_{k} \mid x_{1}, \ldots, x_{k}, y_{1}, \ldots, y_{k}, v_{m}\right)=\prod_{j=1}^{k} \frac{1}{\sigma_{u}} \phi\left(\frac{\Delta i m m_{j}-\beta_{m} x_{j}-\gamma_{m} y_{j}-v_{m}}{\sigma_{u}}\right)
$$

where $\sigma_{u}$ is the standard deviation of the idiosyncratic component in (A5) and $\varphi($.$) is the standard$ normal density function. Similar equations are specified for the two other variables in $z_{t}$.

In order to deal with the potential self-selection of individuals, we allow the unobserved individual effect, $v_{m}$, in (A5) to be correlated with the unobserved individual effects, $v_{e}$ and $v_{u}$, from the hazard model in (A1). The $v^{\prime}$ s are assumed to be uncorrelated with $x_{t}$ and $y_{t}$ and time invariant. Hence, they are constant across repeated spells for the same individual. ${ }^{9}$

The complete contribution to the likelihood function from a job spell is thus:

$$
\left.L=\iiint_{v_{e}, v_{u}, v_{m}} L_{e u}\left(t \mid x_{1}, \ldots, x_{k}, z_{1}, \ldots, z_{k}, v_{e}, v_{u}\right) \cdot L_{m}\left(z_{1}, \ldots, z_{k} \mid x_{1}, \ldots, x_{k}, y_{1}, \ldots, y_{k}, v_{m}\right) d \quad F v_{e}, v_{u}, v_{m}\right)
$$

where $F$ is the joint CDF for the unobserved effects. Note that if selection equations are included for all three immigrant variables, $v_{m}$ is $3 \times 1$ as it then contains three unobserved effects. We use a flexible and widely applied specification of the distribution of these unobservables: It is assumed that they each can take two values, e.g., $v_{e} \in\left\{v_{e 1}, v_{e 2}\right\}$, where one of the support points in each destination specific hazard is normalized to zero (i.e., $v_{e 1}=0$, and $v_{u 1}=0$ ), because the baseline hazard acts as a constant term in the hazard rates. Furthermore, we assume that the elements of $v_{m}$ (if more than one selection equation is included) are perfectly positively correlated but not necessarily of the same size. Thus, there are 8 possible combinations of this unobserved heterogeneity distribution, each with an associated probability. For more details on this class of mixture distributions in duration models, see, e.g., van den Berg (2001).

To estimate the duration model with the selection equations, we rely both on the occurrence of multiple job spells for individuals, as in, e.g., Munch et al. (2006, 2008), and the existence of a set

\footnotetext{
${ }^{9}$ As unobserved individual effects are constant across repeated spells for the same individual, this approach may not eliminate unobserved workplace specific effects which are correlated with the immigrant variables. It is for this reason that we think of $i m m_{t}$ as a proxy for such differences.
} 
of variables (instruments), $y_{t}$, that affect the workplace immigrant share but have no direct impact on job separations. Specifically, we use the following three instruments (one for each immigrant variable): The share of immigrants in employment in the local area (where local areas are defined from observed commuting patterns) as well as the changes in this variable from $t-1$ to $t$ and from $t$ to $t+1$. In the literature on immigration and local labour markets, similar instruments have been applied by, e.g., Card (2001) and Cortes (2008).

\section{Appendix B: Detailed Estimation Results}

Tables A1-A4 below contain the full set of estimation results from the estimations in Tables 3-5 in the paper.

[Insert Tables A1-A4 around here] 


\section{References}

Abowd, J.M. and F. Kramarz (1999): "The Analysis of Labor Markets using Matched EmployerEmployee Data”, in: O. Ashenfelter and D. Card (eds.), Handbook of Labor Economics, vol. 3B, Amsterdam: Elsevier Science, 2629-2710.

Angrist, J.D. and A.D. Kugler (2003): "Protective or Counter Protective? Labour Market Institutions and the Effects of Immigration on EU Natives", Economic Journal, 113, F302F331.

Bender, S., C. Dustmann, D. Margolis, and C. Meghir (2002): "Worker Displacement in France and Germany”, in P.J. Kuhn (ed.), Losing Work, Moving on: International Perspectives on Worker Displacement, W.E. Upjohn Institute for Employment Research.

Battu, H., A. Ma and E. Phimister (2008), "Housing Tenure, Job Mobility and Unemployment in the UK”, Economic Journal, 118, 311-328.

Borjas, G.J., R. Freeman and L. Katz (1997): "How Much Do Immigration and Trade Affect Labor Market Outcomes”, Brookings Papers on Economic Activity, 1, 1-90.

Borland, J., P. Gregg, G. Knight and J. Wadsworth (2002): “The Get Knocked Down. Do They Get Up Again?”, in P.J. Kuhn (ed.), Losing Work, Moving on: International Perspectives on Worker Displacement, W.E. Upjohn Institute for Employment Research.

Browning, M., A.M. Danø and E. Heinesen (2006): “Job Displacement and Stress-Related Health Outcomes”, Health Economics, 15, 1061-1075.

Card, D. (2001): "Immigrant Inflows, Native Outflows, and the Local Market Impacts of Higher Immigration”, Journal of Labor Economics, 19, 22-63.

Cortes, P. (2008): "The Effects of Low-Skilled Immigration on US Prices: Evidence from CPI Data”, Journal of Political Economy, 116, 381-422.

Dustmann, C., F. Fabbri and I. Preston (2005): “The Impact of Immigration on the British Labour Market”, Economic Journal, 115, F324-F341.

Farber, H.S. (1999): “Mobility and Stability: The Dynamics of Job Change in Labor Markets”, in O. Ashenfelter and D. Card (eds.), The Handbook of Labor Economics, 3, Elsevier Science, Holland.

Farber, H.S. (2005): "What do We Know about Job Loss in the United States? Evidence from the Displaced Workers Survey, 1984-2004”, Economic Perspectives, Q2, 13-18.

Geishecker, I. (2008): “The Impact of International Outsourcing on Individual Employment Security: A Micro-Level Analysis”, Labour Economics, 15, 291-314. 
Kiefer, N.M. (1990): “Econometric Methods for Grouped Duration Data”, in J. Hartog, G. Ridder and J. Theeuwes (eds.), Panel Data and Labour Market Studies, North Holland, Amsterdam.

Klein, M.W., S. Schuh and R.K. Triest (2003): "Job Creation, Job Destruction, and the Real Exchange Rate”, Journal of International Economics, 59, 239-265.

Longhi, S., P. Nijkamp and J. Poot (2006): "The Impact of Immigration on the Employment of Natives in Regional Labour Markets: A Meta-Analysis”, IZA Discussion Paper No. 2044, Institute for the Study of Labor (IZA).

Malchow-Møller, N., J.R. Munch, S. Schroll and J.R. Skaksen (2008a): "Attitudes towards Immigration - Perceived Consequences and Economic Self-Interest”, Economics Letters, 100, 254-257.

Malchow-Møller, N., J.R. Munch and J.R. Skaksen (2008b): “Do Immigrants Affect Firm-Specific Wages?” IZA Discussion Paper no. 3264.

Munch, J., M. Rosholm and M. Svarer (2006): “Are Home Owners Really More Unemployed?”, Economic Journal, 116, 991-1013.

Munch, J., M. Rosholm and M. Svarer (2008): "Home Ownership, Job Duration and Wages”, Journal of Urban Economics, 63, 130-145.

Pischke, J.-S. and J. Velling (1997): "Employment Effects of Immigration to Germany: An Analysis Based on Local Labor Markets”, Review of Economics and Statistics, 79, 594-604.

Royalty, A. B. (1998): “Job-to-job and job-to-nonemployment turnover by gender and education level”, Journal of Labor Economics, 16, 392-443.

Sueyoshi, G. T. (1992): "Semiparametric Proportional Hazards Estimation of Competing Risks Models with Time-Varying Covariates”, Journal of Econometrics, 51, 25-58.

van den Berg, G. (2001): “Duration Models: Specification, Identification, and Mulitple Durations”, in J.J. Heckman and E. Leamer (eds.), Handbook of Econometrics, Vol. V, North Holland, Amsterdam. 
Table 1: Job Spell Statistics

Number of persons

51,960

Number of spells

89,492

Share of persons with more than one spell

0.1803

Mean duration of spells (in years)

3.0815

Proportion of spells that:

are right-censored

0.2934

end with job change

0.6051

end with unemployment

0.0539

end with other destinations

0.0475 
Table 2: Summary Statistics

(1)

(2)

Observations in occupations

without immigrants

All observations
Mean Stdv

Individual characteristics:

Age

Age squared

Female

Married

Basic education

Vocational education

Further education

Large city

Small city

Copenhagen

Experience

Occupation dummies (1-digit DISCO):

Managers

Professionals

Technicians and associate professors

Clerical support workers

Service and sales workers

Skilled agricultural, forestry and fishery workers

Craft and related trades workers

Plant and machine operators, and assemblers

Elementary occupations

Workplace characteristics:

Log(\# of employees)

Share with basic education

Share with further education

Share female

Share aged $40+$

Immigrant variables:

imm $_{\text {iwt }}$

$\Delta i m m_{\text {iwt }}$

$L_{\Delta i m m_{i w t}}$
36.85

1469.43

0.3270

0.4856

0.3287

0.4824

0.1889

0.1386

0.6328

0.2286

0.1486

0.0054

0.1012

0.1872

0.1409

0.0662

0.0073

0.2115

0.1526

0.1278

4.5475

0.3427

0.1816

0.3287

0.4199

0.0139

0.0006

0.0137

\subsection{5}

824.41

0.4691

0.4998

0.4698

0.4997

0.3914

0.3455

0.4820

0.4199

0.0930

\subsection{9}

0.3019

0.3901

0.3480

0.2487

0.0852

0.4083

0.3596

0.3338

\subsection{8}

0.1753

0.2016

0.2324

0.1738

0.0369

0.0311

0.0916

Stdv.

10.68

827.17

0.4678

0.4998

0.4652

0.4996

0.3696

0.3542

0.4681

0.3818

0.0928

0.1771

0.1477

0.0083

0.0767

0.1852

0.1712

0.0752

0.0114

0.2309

0.1138

0.1273

3.8980

0.3386

0.1526

0.3222

0.4088

0.000

0.0027

$-0.0016$

\subsection{7}

0.2662

0.3885

0.3767

0.2637

0.1061

0.4214

0.3176

0.3333

1.1396

0.1807

0.1874

0.2462

0.1884

0.000

0.0211

0.0121
(3)

Observations in occupations with immigrants

$\begin{array}{cc}\text { Mean } & \text { Stdv. } \\ & \\ 37.49 & 10.31 \\ 1511.77 & 818.47 \\ 0.3324 & 0.4711 \\ 0.4858 & 0.4998 \\ 0.3465 & 0.4759 \\ 0.4263 & 0.4946 \\ 0.2271 & 0.4190 \\ 0.1259 & 0.3318 \\ 0.5688 & 0.4953 \\ 0.3053 & 0.4605 \\ 0.1499 & 0.0935\end{array}$

\# observations

105,976

63,407

$0.0010 \quad 0.0310$

$0.1376 \quad 0.3445$

$0.1901 \quad 0.3924$

$0.0959 \quad 0.2945$

$0.0528 \quad 0.2237$

$0.0012 \quad 0.0353$

$0.1826 \quad 0.3863$

$0.2102 \quad 0.4075$

$0.1285 \quad 0.3347$

Note: Columns (2) and (3) divide the sample into observations where $i m_{i w t}=0$ (column 2) and where $i m m_{\text {iwt }}>0$ (column 3). See text for explanations of variables.

Note: 1-digit DISCO codes obtained from the International Labour Organization: http://www.ilo.org/public/english/bureau/stat/isco/docs/resol08.pdf 
Table 3: Competing Risks Model

\begin{tabular}{|c|c|c|c|c|}
\hline & $\begin{array}{c}(1) \\
\text { Job change } \\
\text { hazard } \\
\end{array}$ & $\begin{array}{c}(2) \\
\begin{array}{c}\text { Unemployment } \\
\text { hazard }\end{array} \\
\end{array}$ & $\begin{array}{c}(3) \\
\text { Job change } \\
\text { hazard }\end{array}$ & $\begin{array}{c}(4) \\
\text { Unemployment } \\
\text { hazard }\end{array}$ \\
\hline \multirow[t]{2}{*}{$\Delta i m m_{i w t}$} & -0.0886 & -0.2215 & -0.0927 & -0.2194 \\
\hline & $(0.0195)$ & $(0.0254)$ & $(0.0216)$ & $(0.0264)$ \\
\hline \multirow[t]{2}{*}{$L \Delta i m m_{i w t}$} & 0.0166 & -0.0277 & 0.0170 & -0.0256 \\
\hline & $(0.0085)$ & $(0.0109)$ & $(0.0088)$ & $(0.0113)$ \\
\hline \multirow[t]{2}{*}{$i m m_{\text {iwt }}$} & -0.0327 & -0.0166 & -0.0415 & -0.0135 \\
\hline & $(0.0219)$ & $(0.0248)$ & $(0.0246)$ & $(0.0270)$ \\
\hline Selection equations included & \multicolumn{2}{|c|}{ no } & \multicolumn{2}{|c|}{ yes } \\
\hline \# observations & \multicolumn{2}{|c|}{118,842} & \multicolumn{2}{|c|}{118,842} \\
\hline
\end{tabular}


Table 4: Competing Risks Model with Job Growth

\begin{tabular}{|c|c|c|c|c|}
\hline & $\begin{array}{c}(1) \\
\text { Job change } \\
\text { hazard }\end{array}$ & $\begin{array}{c}(2) \\
\text { Unemployment } \\
\text { hazard }\end{array}$ & $\begin{array}{c}(3) \\
\text { Job change } \\
\text { hazard }\end{array}$ & $\begin{array}{c}(4) \\
\begin{array}{c}\text { Unemployment } \\
\text { hazard }\end{array}\end{array}$ \\
\hline \multirow[t]{2}{*}{$\Delta i m m_{t}$} & -0.0884 & -0.2246 & 0.1003 & -0.0679 \\
\hline & $(0.0195)$ & $(0.0254)$ & $(0.0195)$ & $(0.0261)$ \\
\hline \multirow[t]{2}{*}{$L \Delta i m m_{t}$} & 0.0163 & -0.0259 & 0.0081 & -0.0312 \\
\hline & $(0.0086)$ & $(0.0109)$ & $(0.0089)$ & $(0.0110)$ \\
\hline \multirow[t]{2}{*}{$\mathrm{imm}_{t}$} & -0.0336 & -0.0210 & 0.0095 & 0.0198 \\
\hline & $(0.0219)$ & $(0.0248)$ & $(0.0221)$ & $(0.0252)$ \\
\hline \multirow[t]{2}{*}{ Job growth $_{\mathrm{t}-1}$} & 0.0156 & -0.0592 & & \\
\hline & $(0.0248)$ & $(0.0337)$ & & \\
\hline \multirow[t]{2}{*}{ Job growth $_{\mathrm{t}}$} & & & -1.9592 & -1.8680 \\
\hline & & & $(0.0193)$ & $(0.0289)$ \\
\hline \# observations & \multicolumn{2}{|c|}{118,842} & \multicolumn{2}{|c|}{118,842} \\
\hline
\end{tabular}


Table 5: Competing Risks Model - Interaction with Education

\begin{tabular}{|c|c|c|c|c|c|c|}
\hline & $\begin{array}{c}(1) \\
\text { Job change } \\
\text { hazard }\end{array}$ & $\begin{array}{c}(2) \\
\begin{array}{c}\text { Unemployment } \\
\text { hazard }\end{array}\end{array}$ & $\begin{array}{c}(3) \\
\begin{array}{c}\text { Job change } \\
\text { hazard }\end{array}\end{array}$ & $\begin{array}{c}(4) \\
\begin{array}{c}\text { Unemployment } \\
\text { hazard }\end{array} \\
\end{array}$ & $\begin{array}{c}(5) \\
\text { Job change } \\
\text { hazard }\end{array}$ & $\begin{array}{c}(6) \\
\begin{array}{c}\text { Unemployment } \\
\text { hazard }\end{array} \\
\end{array}$ \\
\hline \multirow[t]{2}{*}{$\Delta i m m_{t} \times$ basic education } & -0.1238 & -0.2139 & -0.1228 & -0.2137 & 0.0562 & -0.0719 \\
\hline & $(0.0293)$ & $(0.0347)$ & $(0.0293)$ & $(0.0347)$ & $(0.0305)$ & $(0.0355)$ \\
\hline \multirow[t]{2}{*}{$\Delta i m m_{t} \times$ vocational education } & -0.1047 & -0.2369 & -0.1043 & -0.2363 & 0.0743 & -0.0648 \\
\hline & $(0.0323)$ & $(0.0430)$ & $(0.0323)$ & $(0.0430)$ & $(0.0319)$ & $(0.0438)$ \\
\hline \multirow[t]{2}{*}{$\Delta i m m_{t} \times$ further education } & 0.0478 & -0.2813 & 0.0435 & -0.2775 & 0.2978 & -0.12 \\
\hline & $(0.0466)$ & $(0.0747)$ & $(0.0466)$ & $(0.0746)$ & $(0.0400)$ & $(0.0764)$ \\
\hline \multirow[t]{2}{*}{$L \Delta i m m_{t} \times$ basic education } & -0.0105 & -0.0276 & -0.0105 & -0.0263 & -0.0155 & -0.0317 \\
\hline & $(0.0134)$ & $(0.0135)$ & $(0.0134)$ & $(0.0135)$ & $(0.0143)$ & $(0.0135)$ \\
\hline \multirow[t]{2}{*}{$L \Delta i m m_{t} \times$ vocational education } & 0.0182 & -0.0362 & 0.0186 & -0.0346 & 0.0114 & -0.0383 \\
\hline & $(0.0137)$ & $(0.0201)$ & $(0.0137)$ & $(0.0201)$ & $(0.0141)$ & $(0.0203)$ \\
\hline \multirow[t]{2}{*}{$L \Delta i m m_{t} \times$ further education } & 0.0808 & 0.0111 & 0.0811 & 0.0127 & 0.0533 & 0.0054 \\
\hline & $(0.0181)$ & $(0.0443$ & $(0.0181)$ & $(0.0433)$ & $(0.0187)$ & $(0.0455)$ \\
\hline \multirow[t]{2}{*}{$\mathrm{imm}_{t} \mathrm{x}$ basic education } & -0.0143 & -0.0281 & -0.0147 & -0.0283 & 0.0228 & 0.009 \\
\hline & $(0.0305)$ & $(0.0316)$ & $(0.0305)$ & $(0.0316)$ & $(0.0309)$ & $(0.0321)$ \\
\hline \multirow[t]{2}{*}{$\mathrm{imm}_{t} \times$ vocational education } & -0.0183 & 0.0048 & -0.0196 & 0.0037 & 0.0256 & 0.039 \\
\hline & $(0.0357)$ & $(0.0439)$ & $(0.0357)$ & $(0.0439)$ & $(0.0356)$ & $(0.0435)$ \\
\hline \multirow[t]{2}{*}{$i m m_{t} \times$ further education } & -0.1648 & -0.0604 & -0.1614 & -0.0604 & -0.075 & -0.0097 \\
\hline & $(0.0634)$ & $(0.0821)$ & $(0.0634)$ & $(0.0822)$ & $(0.0645)$ & $(0.0862)$ \\
\hline \multirow[t]{2}{*}{ Job growth ${ }_{t-1}$} & & & 0.0029 & -0.0561 & & \\
\hline & & & $(0.0248)$ & $(0.0337)$ & & \\
\hline \multirow[t]{2}{*}{ Job growth $_{\mathrm{t}}$} & & & & & -1.9552 & -1.8632 \\
\hline & & & & & $(0.0192)$ & $(0.0290)$ \\
\hline
\end{tabular}


Job change hazard Unemployment hazard

Estimates Std. Err. Estimates Std. Err.

Individual characteristics:

Age

Age squared

$\begin{array}{cccc}\mathbf{- 1 . 4 8 3 6} & 0.5337 & \mathbf{2 . 7 0 1 8} & 0.6704 \\ \mathbf{- 0 . 5 7 7 9} & 0.6619 & 0.9483 & 0.8356 \\ \mathbf{- 0 . 2 4 4 7} & 0.0191 & \mathbf{0 . 1 9 5 7} & 0.0273 \\ -0.0046 & 0.0168 & \mathbf{- 0 . 2 9 8 2} & 0.0225 \\ \mathbf{0 . 0 7 5 3} & 0.0179 & 0.0144 & 0.0226 \\ -0.0100 & 0.0268 & \mathbf{- 0 . 1 4 2 0} & 0.0415 \\ \mathbf{- 0 . 2 1 6 4} & 0.0247 & \mathbf{0 . 1 4 6 8} & 0.0339 \\ \mathbf{- 0 . 1 7 8 5} & 0.0180 & 0.0316 & 0.0269 \\ \mathbf{0 . 5 2 8 1} & 0.1446 & \mathbf{- 5 . 4 7 3 5} & 0.1771\end{array}$

Married

Vocational education

Further education

Large city

Small city

Experience

$-5.4735$

Occupation dummies:

Managers

0.8341

0.3963

0.0818

0.4095

0.1072

Professionals

0.4461

0.0365

$-0.6468$

0.0626

Technicians and associate professors

0.0292

$\mathbf{0 . 3 4 4 0} \quad 0.0304$

$-0.4835 \quad 0.0434$

Clerical support workers

0.5663

0.0342

$-0.2437 \quad 0.0391$

Service and sales workers

$\begin{array}{ll}0.0922 & 0.0889 \\ 0.1019 & 0.0279\end{array}$

$0.0486 \quad 0.0433$

Skilled agricultural, forestry and fishery workers

Craft and related trades workers

$\begin{array}{ll}\mathbf{0 . 1 0 1 9} & 0.0279 \\ \mathbf{0 . 0 6 7 5} & 0.0293\end{array}$

$-0.1676$

0.1018

Plant and machine operators, and assemblers

$0.1356 \quad 0.0318$

$0.1501 \quad 0.0312$

Workplace characteristics:

Log(\# of employees)

$\begin{array}{rr}-0.5403 & 0.0534\end{array}$

$\mathbf{0 . 4 7 1 2} 0.0526$

$-1.4392 \quad 0.0756$

Share with basic education

Share with further education

$\mathbf{0 . 1 1 9 9} \quad 0.0514$

$1.0109 \quad 0.0671$

Share female

$0.0254 \quad 0.0369$

$\mathbf{- 0 . 2 7 8 8} 0.0826$

Share aged $40+$

$-0.1859$

0.0441

$\begin{array}{ll}-0.2218 & 0.0497\end{array}$

Immigrant variables:

$\Delta i m m_{t}$

$\begin{array}{cccc}\mathbf{- 0 . 0 8 8 6} & 0.0195 & \mathbf{- 0 . 2 2 1 5} & 0.0254 \\ 0.0166 & 0.0085 & \mathbf{- 0 . 0 2 7 7} & 0.0109 \\ -0.0327 & 0.0219 & -0.0166 & 0.0248\end{array}$

Baseline hazard parameters:

$\Lambda_{1}$

$\Lambda_{2}$

$0.1504 \quad 0.0200$

$0.3419 \quad 0.0359$

$\mathbf{0 . 1 0 3 8} 0.0139$

$\Lambda_{3}$

$0.3250 \quad 0.0344$

$\mathbf{0 . 0 8 9 0} \quad 0.0120$

$\begin{array}{llll}\mathbf{0 . 2 9 4 5} & 0.0316 & \mathbf{0 . 0 7 9 6} & 0.0111\end{array}$

$\Lambda_{4}$

$0.2716 \quad 0.0299$

$0.0707 \quad 0.0102$

$\Lambda_{6}$

$\mathbf{0 . 2 4 3 2} \quad 0.0276$

$\mathbf{0 . 0 6 0 4} 0.0092$

$\Lambda_{7}$

$\mathbf{0 . 2 0 4 6} 0.0246$

$\mathbf{0 . 0 5 8 3} 0.0095$

$\Lambda_{8}$

$\mathbf{0 . 1 7 8 9} \quad 0.0235$

$\mathbf{0 . 0 4 7 4} 0.0086$

$\Lambda_{9}$

$0.1431 \quad 0.0223$

$\mathbf{0 . 0 4 1 1} 0.0094$

$\Lambda_{10}$

$\mathbf{0 . 1 3 7 4} 0.0291$

0.0557

0.0152

Unobserved heterogeneity parameters:

$\begin{array}{lll}v_{e 2} & \mathbf{1 . 1 8 2 8} & 0.0350 \\ v_{u 2} & \mathbf{1 . 6 8 1 8} & 0.0364 \\ \mathrm{P}\left(v_{e}=v_{e 1}, v_{u}=v_{u 1}\right) & \mathbf{0 . 7 8 7 5} & 0.0094 \\ \mathrm{P}\left(v_{e}=v_{e 2}, v_{u}=v_{u 1}\right) & 0.0007 & 0.0090 \\ \mathrm{P}\left(v_{e}=v_{e 1}, v_{u}=v_{u 2}\right) & 0.0006 & 0.0098 \\ \mathrm{P}\left(v_{e}=v_{e 2}, v_{u}=v_{u 2}\right) & \mathbf{0 . 2 1 1 2} & 0.0114\end{array}$


Table A2: Competing Risks Model with Selection Equations

\begin{tabular}{|c|c|c|c|c|c|c|c|c|c|c|}
\hline & \multicolumn{2}{|c|}{ Job change hazard } & \multicolumn{2}{|c|}{ Unemployment hazard } & \multicolumn{2}{|c|}{$\begin{array}{c}\text { Selection equation } \\
\Delta i m m_{t}\end{array}$} & \multicolumn{2}{|c|}{ 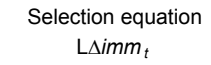 } & \multicolumn{2}{|c|}{$\begin{array}{c}\text { Selection equation } \\
\mathrm{imm}_{t}\end{array}$} \\
\hline & Estimates & Std. Err. & Estimates & Std. Err. & Estimates & Std. Err. & Estimates & Std. Err. & Estimates & Std. Err. \\
\hline \multicolumn{11}{|l|}{ Individual characteristics: } \\
\hline Age & -1.5116 & 0.5352 & 2.7957 & 0.6728 & 0.0084 & 0.0720 & 0.4503 & 0.1884 & 0.2062 & 0.0504 \\
\hline Age squared & -0.5269 & 0.6637 & 0.8040 & 0.8391 & -0.0410 & 0.0888 & -0.2228 & 0.2289 & 0.0499 & 0.0617 \\
\hline Female & -0.2448 & 0.0191 & 0.1972 & 0.0275 & -0.0035 & 0.0027 & 0.0335 & 0.0067 & 0.0036 & 0.0019 \\
\hline Married & -0.0027 & 0.0168 & -0.2975 & 0.0225 & -0.0014 & 0.0023 & 0.0044 & 0.0057 & 0.0015 & 0.0016 \\
\hline Vocational education & 0.0746 & 0.0180 & 0.0154 & 0.0227 & -0.0005 & 0.0025 & -0.0125 & 0.0060 & -0.0002 & 0.0017 \\
\hline Further education & -0.0077 & 0.0269 & -0.1380 & 0.0417 & -0.0039 & 0.0044 & -0.0235 & 0.0114 & -0.0032 & 0.0030 \\
\hline Large city & -0.2207 & 0.0248 & 0.1498 & 0.0340 & -0.0109 & 0.0043 & 0.0118 & 0.0108 & 0.0107 & 0.0030 \\
\hline Small city & -0.1817 & 0.0181 & 0.0342 & 0.0270 & -0.0083 & 0.0028 & 0.0068 & 0.0077 & -0.0034 & 0.0020 \\
\hline Experience & 0.4781 & 0.1452 & -5.4714 & 0.1783 & 0.0194 & 0.0192 & -0.2595 & 0.0488 & -0.2928 & 0.0137 \\
\hline \multicolumn{11}{|l|}{ Occupation dummies: } \\
\hline Managers & 0.8271 & 0.0821 & 0.4119 & 0.1077 & -0.0088 & 0.0437 & -0.2153 & 0.0998 & -0.1568 & 0.0218 \\
\hline Professionals & 0.3912 & 0.0366 & -0.6433 & 0.0628 & 0.0137 & 0.0062 & -0.1410 & 0.0167 & -0.0496 & 0.0047 \\
\hline Technicians and associate professors & 0.4402 & 0.0293 & -0.4824 & 0.0435 & 0.0051 & 0.0047 & -0.1445 & 0.0125 & -0.0921 & 0.0039 \\
\hline Clerical support workers & 0.3382 & 0.0305 & -0.2417 & 0.0393 & -0.0031 & 0.0050 & -0.1862 & 0.0136 & -0.0944 & 0.0032 \\
\hline Service and sales workers & 0.5612 & 0.0343 & 0.0526 & 0.0435 & 0.0071 & 0.0042 & -0.1942 & 0.0173 & -0.0368 & 0.0035 \\
\hline Skilled agricultural, forestry and fishery workers & 0.0805 & 0.0892 & -0.1501 & 0.1024 & 0.0072 & 0.0186 & -0.1568 & 0.0709 & -0.1191 & 0.0177 \\
\hline Craft and related trades workers & 0.0956 & 0.0280 & 0.1363 & 0.0320 & -0.0017 & 0.0040 & -0.0863 & 0.0103 & -0.0179 & 0.0029 \\
\hline Plant and machine operators, and assemblers & 0.0651 & 0.0294 & 0.1500 & 0.0314 & 0.0070 & 0.0030 & 0.0120 & 0.0073 & 0.0738 & 0.0021 \\
\hline \multicolumn{11}{|l|}{ Workplace characteristics: } \\
\hline Log(\# of employees) & -0.5361 & 0.0538 & -1.4293 & 0.0761 & -0.0146 & 0.0089 & 0.3582 & 0.0239 & 0.1194 & 0.0054 \\
\hline Share with basic education & 0.4545 & 0.0527 & 1.0250 & 0.0674 & -0.0091 & 0.0075 & 0.2282 & 0.0254 & 0.2173 & 0.0064 \\
\hline Share with further education & 0.1048 & 0.0516 & -0.2803 & 0.0829 & 0.0189 & 0.0093 & 0.0756 & 0.0281 & 0.0858 & 0.0067 \\
\hline Share female & 0.0259 & 0.0371 & -0.2219 & 0.0499 & 0.0018 & 0.0051 & 0.0833 & 0.0144 & 0.0240 & 0.0038 \\
\hline Share aged $40+$ & -0.1838 & 0.0443 & -0.1657 & 0.0592 & -0.0351 & 0.0061 & -0.1144 & 0.0202 & -0.0690 & 0.0048 \\
\hline \multicolumn{11}{|l|}{ Immigrant variables: } \\
\hline$\Delta i m m_{t}$ & -0.0927 & 0.0216 & -0.2194 & 0.0264 & & & & & & \\
\hline$L_{\Delta i m m_{t}}$ & 0.0170 & 0.0088 & -0.0256 & 0.0113 & & & & & & \\
\hline$i m m_{t}$ & -0.0415 & 0.0246 & -0.0135 & 0.0270 & & & & & & \\
\hline \multicolumn{11}{|l|}{ Instruments: } \\
\hline Immigrant share (local area) & & & & & -0.1889 & 0.0761 & 1.5354 & 0.1876 & 2.2398 & 0.0527 \\
\hline$\Delta$ Immigrant share $(\text { local area })_{t}$ & & & & & 0.0016 & 0.0014 & 0.0045 & 0.0030 & 0.0004 & 0.0017 \\
\hline L $\Delta$ Immigrant share (local area $)_{t}$ & & & & & 0.0006 & 0.0012 & 0.0155 & 0.0028 & 0.0002 & 0.0017 \\
\hline \multicolumn{11}{|l|}{ Baseline hazard parameters: } \\
\hline$\Lambda_{1}$ & 0.4073 & 0.0425 & 0.1430 & 0.0191 & & & & & & \\
\hline$\Lambda_{2}$ & 0.3458 & 0.0364 & 0.0986 & 0.0133 & & & & & & \\
\hline$\Lambda_{3}$ & 0.3310 & 0.0351 & 0.0845 & 0.0115 & & & & & & \\
\hline$\Lambda_{4}$ & 0.2999 & 0.0323 & 0.0757 & 0.0106 & & & & & & \\
\hline$\Lambda_{5}$ & 0.2761 & 0.0305 & 0.0679 & 0.0098 & & & & & & \\
\hline$\Lambda_{6}$ & 0.2483 & 0.0283 & 0.0574 & 0.0087 & & & & & & \\
\hline$\Lambda_{7}$ & 0.2088 & 0.0252 & 0.0555 & 0.0091 & & & & & & \\
\hline$\Lambda_{8}$ & 0.1827 & 0.0241 & 0.0460 & 0.0084 & & & & & & \\
\hline$\Lambda_{9}$ & 0.1506 & 0.0235 & 0.0364 & 0.0083 & & & & & & \\
\hline$\Lambda_{10}$ & 0.1307 & 0.0278 & 0.0491 & 0.0134 & & & & & & \\
\hline \multicolumn{11}{|l|}{ Unobserved heterogeneity parameters: } \\
\hline$v_{e 2}$ & 1.1651 & 0.0347 & & & & & & & & \\
\hline$v_{u 2}$ & 1.6676 & 0.0361 & & & & & & & & \\
\hline$v_{m 1}$ & & & & & 0.0449 & 0.0158 & -0.1966 & 0.0425 & -0.1184 & 0.0109 \\
\hline$v_{m 2}$ & & & & & -0.2069 & 0.0160 & 0.9303 & 0.0424 & 1.1383 & 0.0111 \\
\hline $\mathrm{P}\left(v_{e}=v_{e 1}, v_{u}=v_{u 1}, v_{m}=v_{m 1}\right)$ & 0.753 & 0.010 & & & & & & & & \\
\hline $\mathrm{P}\left(v_{e}=v_{e 2}, v_{u}=v_{u 1}, v_{m}=v_{m 1}\right)$ & 0.001 & 0.009 & & & & & & & & \\
\hline $\mathrm{P}\left(v_{e}=v_{e 1}, v_{u}=v_{u 2}, v_{m}=v_{m 1}\right)$ & 0.001 & 0.010 & & & & & & & & \\
\hline $\mathrm{P}\left(v_{e}=v_{e 2}, v_{u}=v_{u 2}, v_{m}=v_{m 1}\right)$ & 0.213 & 0.012 & & & & & & & & \\
\hline $\mathrm{P}\left(v_{e}=v_{e 1}, v_{u}=v_{u 1}, v_{m}=v_{m 2}\right)$ & 0.024 & 0.002 & & & & & & & & \\
\hline $\mathrm{P}\left(v_{e}=v_{e 2}, v_{u}=v_{u 1}, v_{m}=v_{m 2}\right)$ & 0.001 & 0.002 & & & & & & & & \\
\hline $\mathrm{P}\left(v_{e}=v_{e 1}, v_{u}=v_{u 2}, v_{m}=v_{m 2}\right)$ & 0.001 & 0.002 & & & & & & & & \\
\hline $\mathrm{P}\left(v_{e}=v_{e 2}, v_{u}=v_{u 2}, v_{m}=v_{m 2}\right)$ & 0.005 & 0.002 & & & & & & & & \\
\hline $\operatorname{Var}(u)$ & & & & & -2.2370 & 0.0007 & -0.2108 & 0.0016 & -2.2973 & 0.0011 \\
\hline $\operatorname{Corr}\left(v_{e}, v_{m}\right)$ & -0.0105 & 0.0805 & & & & & & & & \\
\hline $\operatorname{Corr}\left(v_{u}, v_{m}\right)$ & -0.0156 & 0.0955 & & & & & & & & \\
\hline \# observations & 118,842 & & & & & & & & & \\
\hline
\end{tabular}

equations is restricted to be perfect. The standard errors for the correlation coefficients have been calculated based on 1000 drawings from the multivariate normal distribution with mean and covariance matrix set
ention equal to the estimated parameter vector and covariance matrix. 


\begin{tabular}{|c|c|c|c|c|c|c|c|c|}
\hline & \multicolumn{2}{|c|}{ Job change hazard } & \multicolumn{2}{|c|}{ Unemployment hazard } & \multicolumn{2}{|c|}{ Job change hazard } & \multicolumn{2}{|c|}{ Unemployment hazard } \\
\hline & Estimates & Std. Err. & Estimates & Std. Err. & Estimates & Std. Err. & Estimates & Std. Err. \\
\hline \multicolumn{9}{|l|}{ Individual characteristics: } \\
\hline Age & -1.4881 & 0.5338 & 2.7050 & 0.6708 & -1.4912 & 0.5440 & 2.7216 & 0.6720 \\
\hline Age squared & -0.5757 & 0.6619 & 0.9355 & 0.8360 & -0.6131 & 0.6760 & 0.8511 & 0.8408 \\
\hline Female & -0.2445 & 0.0191 & 0.1941 & 0.0273 & -0.2611 & 0.0195 & 0.1796 & 0.0273 \\
\hline Married & -0.0042 & 0.0168 & -0.2972 & 0.0225 & -0.0009 & 0.0171 & -0.2924 & 0.0226 \\
\hline Vocational education & 0.0750 & 0.0179 & 0.0155 & 0.0226 & 0.0766 & 0.0183 & 0.0250 & 0.0228 \\
\hline Further education & -0.0091 & 0.0268 & -0.1402 & 0.0415 & -0.0067 & 0.0274 & -0.1294 & 0.0403 \\
\hline Large city & -0.2188 & 0.0247 & 0.1485 & 0.0339 & -0.2116 & 0.0252 & 0.1780 & 0.0342 \\
\hline Small city & -0.1797 & 0.0180 & 0.0307 & 0.0269 & -0.1718 & 0.0183 & 0.0483 & 0.0273 \\
\hline Experience & 0.5242 & 0.1446 & -5.4769 & 0.1771 & 0.4978 & 0.1479 & -5.4765 & 0.1763 \\
\hline \multicolumn{9}{|l|}{ Occupation dummies: } \\
\hline Managers & 0.8335 & 0.0818 & 0.4063 & 0.1073 & 0.8288 & 0.0827 & 0.3907 & 0.1067 \\
\hline Professionals & 0.3956 & 0.0365 & -0.6459 & 0.0626 & 0.4070 & 0.0375 & -0.6332 & 0.0633 \\
\hline Technicians and associate professors & 0.4452 & 0.0292 & -0.4851 & 0.0434 & 0.4389 & 0.0300 & -0.4750 & 0.0438 \\
\hline Clerical support workers & 0.3441 & 0.0304 & -0.2439 & 0.0391 & 0.3397 & 0.0313 & -0.2369 & 0.0395 \\
\hline Service and sales workers & 0.5662 & 0.0342 & 0.0491 & 0.0433 & 0.5280 & 0.0349 & 0.0252 & 0.0431 \\
\hline Skilled agricultural, forestry and fishery workers & 0.0886 & 0.0890 & -0.1648 & 0.1018 & 0.0966 & 0.0911 & -0.1653 & 0.0999 \\
\hline Craft and related trades workers & 0.1020 & 0.0279 & 0.1336 & 0.0318 & 0.0921 & 0.0288 & 0.1185 & 0.0323 \\
\hline Plant and machine operators, and assemblers & 0.0684 & 0.0293 & 0.1514 & 0.0312 & 0.0816 & 0.0303 & 0.1572 & 0.0317 \\
\hline \multicolumn{9}{|l|}{ Workplace characteristics: } \\
\hline Log(\# of employees) & -0.5382 & 0.0536 & -1.4323 & 0.0756 & -0.6080 & 0.0549 & -1.4680 & 0.0772 \\
\hline Share with basic education & 0.4686 & 0.0526 & 1.0133 & 0.0672 & 0.3796 & 0.0535 & 0.9342 & 0.0677 \\
\hline Share with further education & 0.1166 & 0.0514 & -0.2786 & 0.0826 & 0.1465 & 0.0530 & -0.2110 & 0.0837 \\
\hline Share female & 0.0285 & 0.0370 & -0.2226 & 0.0497 & 0.0657 & 0.0378 & -0.2208 & 0.0493 \\
\hline Share aged $40+$ & -0.1842 & 0.0444 & -0.1809 & 0.0594 & -0.2797 & 0.0453 & -0.2217 & 0.0600 \\
\hline \multicolumn{9}{|l|}{ Immigrant variables: } \\
\hline$\Delta i m m_{t}$ & -0.0884 & 0.0195 & -0.2246 & 0.0254 & 0.1003 & 0.0195 & -0.0679 & 0.0261 \\
\hline$L_{\Delta} \mathrm{imm}_{t}$ & 0.0163 & 0.0086 & -0.0259 & 0.0109 & 0.0081 & 0.0089 & -0.0312 & 0.0110 \\
\hline$i m m_{t}$ & -0.0336 & 0.0219 & -0.0210 & 0.0248 & 0.0095 & 0.0221 & 0.0198 & 0.0252 \\
\hline \multicolumn{9}{|l|}{ Growth variables: } \\
\hline Job growth & 0.0156 & 0.0248 & -0.0592 & 0.0337 & & & & \\
\hline Job growth & & & & & -1.9592 & 0.0193 & -1.8680 & 0.0289 \\
\hline \multicolumn{9}{|l|}{ Baseline hazard parameters: } \\
\hline$\Lambda_{1}$ & 0.4017 & 0.0418 & 0.1516 & 0.0201 & 0.4322 & 0.0455 & 0.1649 & 0.0219 \\
\hline$\Lambda_{2}$ & 0.3419 & 0.0359 & 0.1037 & 0.0139 & 0.3592 & 0.0382 & 0.1102 & 0.0148 \\
\hline$\Lambda_{3}$ & 0.3262 & 0.0345 & 0.0889 & 0.0120 & 0.3431 & 0.0369 & 0.0937 & 0.0127 \\
\hline$\Lambda_{4}$ & 0.2956 & 0.0317 & 0.0794 & 0.0110 & 0.3055 & 0.0333 & 0.0812 & 0.0113 \\
\hline$\Lambda_{5}$ & 0.2718 & 0.0300 & 0.0706 & 0.0102 & 0.2753 & 0.0309 & 0.0714 & 0.0103 \\
\hline$\Lambda_{6}$ & 0.2441 & 0.0277 & 0.0601 & 0.0091 & 0.2470 & 0.0286 & 0.0595 & 0.0091 \\
\hline$\Lambda_{7}$ & 0.2049 & 0.0247 & 0.0581 & 0.0094 & 0.2067 & 0.0253 & 0.0568 & 0.0093 \\
\hline$\Lambda_{8}$ & 0.1788 & 0.0235 & 0.0475 & 0.0087 & 0.1805 & 0.0241 & 0.0471 & 0.0086 \\
\hline$\Lambda_{9}$ & 0.1438 & 0.0224 & 0.0408 & 0.0093 & 0.1459 & 0.0231 & 0.0391 & 0.0091 \\
\hline$\Lambda_{10}$ & 0.1368 & 0.0290 & 0.0556 & 0.0151 & 0.1353 & 0.0294 & 0.0550 & 0.0151 \\
\hline \multicolumn{9}{|l|}{ Unobserved heterogeneity parameters: } \\
\hline$v_{\mathrm{e} 2}$ & 1.1832 & 0.0351 & & & 1.3138 & 0.0421 & & \\
\hline$v_{u 2}$ & 1.6835 & 0.0364 & & & 1.7973 & 0.0432 & & \\
\hline $\mathrm{P}\left(v_{e}=v_{e 1}, v_{u}=v_{u 1}\right)$ & 0.788 & 0.0094 & & & 0.840 & 0.0076 & & \\
\hline $\mathrm{P}\left(v_{e}=v_{e 2}, v_{u}=v_{u 1}\right)$ & 0.001 & 0.0090 & & & 0.001 & 0.0074 & & \\
\hline $\mathrm{P}\left(v_{e}=v_{e 1}, v_{u}=v_{u 2}\right)$ & 0.001 & 0.0097 & & & 0.000 & 0.0081 & & \\
\hline $\mathrm{P}\left(v_{e}=v_{e 2}, v_{u}=v_{u 2}\right)$ & 0.211 & 0.0114 & & & 0.159 & 0.0093 & & \\
\hline \# observations & \multicolumn{4}{|c|}{118,842} & \multicolumn{4}{|c|}{118,842} \\
\hline
\end{tabular}


Table A4: Competing Risks Model - Interaction with Education

\begin{tabular}{|c|c|c|c|c|c|c|c|c|c|c|c|c|}
\hline & \multicolumn{2}{|c|}{ Job change hazard } & \multicolumn{2}{|c|}{ Unemployment hazard } & \multicolumn{2}{|c|}{ Job change hazard } & \multicolumn{2}{|c|}{ Unemployment hazard } & \multicolumn{2}{|c|}{ Job change hazard } & \multicolumn{2}{|c|}{ Unemployment hazard } \\
\hline & Estimates & Std. Err. & Estimates & Std. Err. & Estimates & Std. Err. & Estimates & Std. Err. & Estimates & Std. Err. & Estimates & Std. Err. \\
\hline \multicolumn{13}{|l|}{ Individual characteristics: } \\
\hline Age & -1.4944 & 0.5339 & 2.7239 & 0.6708 & -1.4969 & 0.5340 & 2.7275 & 0.6712 & -1.5174 & 0.5482 & 2.7641 & 0.6301 \\
\hline Age squared & -0.5584 & 0.6620 & 0.8835 & 0.8362 & -0.5571 & 0.6622 & 0.8793 & 0.8366 & -0.5875 & 0.6808 & 0.7954 & 0.7929 \\
\hline Female & -0.2446 & 0.0191 & 0.1951 & 0.0273 & -0.2455 & 0.0191 & 0.1949 & 0.0274 & -0.2595 & 0.0195 & 0.1819 & 0.0274 \\
\hline Married & -0.0037 & 0.0168 & -0.2966 & 0.0225 & -0.0039 & 0.0168 & -0.2965 & 0.0225 & 0.0006 & 0.0171 & -0.2932 & 0.0225 \\
\hline Vocational education & 0.0711 & 0.0189 & 0.0110 & 0.0240 & 0.0715 & 0.0189 & 0.0111 & 0.0240 & 0.0734 & 0.0193 & 0.0191 & 0.0242 \\
\hline Further education & -0.0056 & 0.0277 & -0.1424 & 0.0431 & -0.0063 & 0.0277 & -0.1421 & 0.0431 & -0.0051 & 0.0283 & -0.1362 & 0.0434 \\
\hline Large city & -0.2182 & 0.0247 & 0.1485 & 0.0339 & -0.2181 & 0.0247 & 0.1498 & 0.0339 & -0.2131 & 0.0253 & 0.1718 & 0.0342 \\
\hline Small city & -0.1800 & 0.0180 & 0.0320 & 0.0269 & -0.1802 & 0.0180 & 0.0320 & 0.0269 & -0.1738 & 0.0183 & 0.0428 & 0.0272 \\
\hline Experience & 0.5113 & 0.1447 & -5.4608 & 0.1774 & 0.5108 & 0.1447 & -5.4646 & 0.1774 & 0.5004 & 0.1480 & -5.4570 & 0.1759 \\
\hline \multicolumn{13}{|l|}{ Occupation dummies: } \\
\hline Managers & 0.8299 & 0.0819 & 0.4065 & 0.1073 & 0.8298 & 0.0819 & 0.4063 & 0.1074 & 0.8299 & 0.0828 & 0.3897 & 0.1068 \\
\hline Professionals & 0.3949 & 0.0365 & -0.6402 & 0.0627 & 0.3948 & 0.0365 & -0.6409 & 0.0627 & 0.4089 & 0.0375 & -0.6285 & 0.0637 \\
\hline Technicians and associate professors & 0.4421 & 0.0292 & -0.4829 & 0.0435 & 0.4417 & 0.0292 & -0.4829 & 0.0435 & 0.4400 & 0.0301 & -0.4722 & 0.0439 \\
\hline Clerical support workers & 0.3411 & 0.0304 & -0.2417 & 0.0391 & 0.3407 & 0.0304 & -0.2417 & 0.0392 & 0.3407 & 0.0313 & -0.2369 & 0.0395 \\
\hline Service and sales workers & 0.5628 & 0.0342 & 0.0517 & 0.0433 & 0.5629 & 0.0342 & 0.0514 & 0.0433 & 0.5296 & 0.0349 & 0.0267 & 0.0431 \\
\hline Skilled agricultural, forestry and fishery workers & 0.0869 & 0.0890 & -0.1559 & 0.1018 & 0.0857 & 0.0890 & -0.1563 & 0.1018 & 0.0982 & 0.0911 & -0.1629 & 0.1000 \\
\hline Craft and related trades workers & 0.0991 & 0.0279 & 0.1349 & 0.0318 & 0.0998 & 0.0279 & 0.1364 & 0.0318 & 0.0936 & 0.0288 & 0.1194 & 0.0322 \\
\hline Plant and machine operators, and assemblers & 0.0658 & 0.0293 & 0.1524 & 0.0312 & 0.0659 & 0.0293 & 0.1525 & 0.0312 & 0.0841 & 0.0303 & 0.1575 & 0.0317 \\
\hline \multicolumn{13}{|l|}{ Workplace characteristics: } \\
\hline $\log (\#$ of employees) & -0.5400 & 0.0535 & -1.4322 & 0.0756 & -0.5411 & 0.0536 & -1.4305 & 0.0757 & -0.6094 & 0.0550 & -1.4615 & 0.0773 \\
\hline Share with basic education & 0.4647 & 0.0526 & 1.0169 & 0.0672 & 0.4645 & 0.0526 & 1.0164 & 0.0672 & 0.3771 & 0.0535 & 0.9381 & 0.0676 \\
\hline Share with further education & 0.1202 & 0.0516 & -0.2753 & 0.0826 & 0.1183 & 0.0516 & -0.2772 & 0.0827 & 0.1447 & 0.0532 & -0.2118 & 0.0841 \\
\hline Share female & 0.0298 & 0.0370 & -0.2217 & 0.0497 & 0.0303 & 0.0370 & -0.2210 & 0.0498 & 0.0619 & 0.0379 & -0.2280 & 0.0503 \\
\hline Share aged $40+$ & -0.1848 & 0.0442 & -0.1720 & 0.0590 & -0.1824 & 0.0444 & -0.1716 & 0.0594 & -0.2754 & 0.0454 & -0.2229 & 0.0599 \\
\hline \multicolumn{13}{|l|}{ Immigrant variables: } \\
\hline$\Delta \operatorname{simm}_{t} \times$ basic edu. & -0.1238 & 0.0293 & -0.2139 & 0.0347 & -0.1228 & 0.0293 & -0.2137 & 0.0347 & 0.0562 & 0.0305 & -0.0719 & 0.0355 \\
\hline$\Delta i m m_{t} \times$ vocational edu & -0.1047 & 0.0323 & -0.2369 & 0.0430 & -0.1043 & 0.0323 & -0.2363 & 0.0430 & 0.0743 & 0.0319 & -0.0648 & 0.0438 \\
\hline$\Delta i m m_{t} \times$ further edu & 0.0478 & 0.0466 & -0.2813 & 0.0747 & 0.0435 & 0.0466 & -0.2775 & 0.0746 & 0.2978 & 0.0400 & -0.1200 & 0.0764 \\
\hline$L_{\Delta i m m} \times$ basic edu. & -0.0105 & 0.0134 & -0.0276 & 0.0135 & -0.0105 & 0.0134 & -0.0263 & 0.0135 & -0.0155 & 0.0143 & -0.0317 & 0.0135 \\
\hline L $\Delta$ immt $\times$ vocational edu. & 0.0182 & 0.0137 & -0.0362 & 0.0201 & 0.0186 & 0.0137 & -0.0346 & 0.0201 & 0.0114 & 0.0141 & -0.0383 & 0.0203 \\
\hline$L \Delta i m m_{t} \times$ further edu. & 0.0808 & 0.0181 & 0.0111 & 0.0443 & 0.0811 & 0.0181 & 0.0127 & 0.0443 & 0.0533 & 0.0187 & 0.0054 & 0.0455 \\
\hline$i m m_{t} \times$ basic edu & -0.0143 & 0.0305 & -0.0281 & 0.0316 & -0.0147 & 0.0305 & -0.0283 & 0.0316 & 0.0228 & 0.0309 & 0.0090 & 0.0321 \\
\hline $\mathrm{imm}_{t} \times$ vocational edu & -0.0186 & 0.0357 & 0.0048 & 0.0439 & -0.0196 & 0.0357 & 0.0037 & 0.0439 & 0.0256 & 0.0356 & 0.0390 & 0.0435 \\
\hline$i m m_{t} \times$ further $e d u$ & -0.1648 & 0.0634 & -0.0604 & 0.0821 & -0.1614 & 0.0634 & -0.0604 & 0.0822 & -0.0750 & 0.0645 & -0.0097 & 0.0862 \\
\hline \multicolumn{13}{|l|}{ Growth variables: } \\
\hline Job growth $_{t-1}$ & & & & & 0.0029 & 0.0248 & -0.0561 & 0.0337 & & & & \\
\hline Job growth $\mathrm{t}_{\mathrm{t}}$ & & & & & & & & & -1.9552 & 0.0192 & -1.8632 & 0.0290 \\
\hline \multicolumn{13}{|l|}{ Baseline hazard parameters: } \\
\hline$\Lambda_{1}$ & 0.4053 & 0.0421 & 0.1491 & 0.0198 & 0.4049 & 0.0421 & 0.1500 & 0.0199 & 0.4356 & 0.0461 & 0.1647 & 0.0202 \\
\hline$\Lambda_{2}$ & 0.3445 & 0.0361 & 0.1028 & 0.0138 & 0.3446 & 0.0362 & 0.1025 & 0.0138 & 0.3624 & 0.0388 & 0.1099 & 0.0137 \\
\hline$\Lambda_{3}$ & 0.3284 & 0.0347 & 0.0881 & 0.0119 & 0.3282 & 0.0347 & 0.0879 & 0.0119 & 0.3460 & 0.0374 & 0.0935 & 0.0118 \\
\hline$\Lambda_{4}$ & 0.2978 & 0.032 & 0.0786 & 0.0109 & 0.2978 & 0.0320 & 0.0786 & 0.0109 & 0.3074 & 0.0337 & 0.0810 & 0.0105 \\
\hline$\Lambda_{5}$ & 0.2739 & 0.0302 & 0.0698 & 0.0101 & 0.2742 & 0.0302 & 0.0698 & 0.0101 & 0.2774 & 0.0313 & 0.0712 & 0.0097 \\
\hline$\Lambda_{6}$ & 0.2461 & 0.0279 & 0.0593 & 0.009 & 0.2462 & 0.0280 & 0.0593 & 0.0090 & 0.2486 & 0.0289 & 0.0592 & 0.0085 \\
\hline$\Lambda_{7}$ & 0.2067 & 0.0249 & 0.0573 & 0.0093 & 0.2069 & 0.0249 & 0.0573 & 0.0093 & 0.2082 & 0.0256 & 0.0563 & 0.0087 \\
\hline$\Lambda_{8}$ & 0.1802 & 0.0237 & 0.0477 & 0.0087 & 0.1803 & 0.0237 & 0.0476 & 0.0087 & 0.1818 & 0.0244 & 0.0467 & 0.0083 \\
\hline$\Lambda_{9}$ & 0.1469 & 0.0229 & 0.0401 & 0.0092 & 0.1470 & 0.0229 & 0.0399 & 0.0091 & 0.1472 & 0.0234 & 0.0384 & 0.0087 \\
\hline$\Lambda_{10}$ & 0.1351 & 0.0286 & 0.0546 & 0.0149 & 0.1350 & 0.0286 & 0.0546 & 0.0149 & 0.1345 & 0.0293 & 0.0540 & 0.0145 \\
\hline \multicolumn{13}{|l|}{ Unobserved heterogeneity parameters: } \\
\hline$v_{\mathrm{e} 2}$ & 1.1831 & 0.0351 & & & 1.1834 & 0.0350 & & & 1.3186 & 0.0423 & & \\
\hline$v_{u 2}$ & 1.6815 & 0.0365 & & & 1.6835 & 0.0364 & & & 1.8004 & 0.0434 & & \\
\hline $\mathrm{P}\left(v_{e}=v_{e 1}, v_{u}=v_{u 1}\right)$ & 0.7878 & 0.0094 & & & 0.7876 & 0.0094 & & & 0.8413 & 0.0075 & & \\
\hline $\mathrm{P}\left(v_{e}=v_{e 2}, v_{u}=v_{u 1}\right)$ & 0.0007 & 0.0090 & & & 0.0007 & 0.0090 & & & 0.0005 & 0.0073 & & \\
\hline $\mathrm{P}\left(v_{e}=v_{e 1}, v_{u}=v_{u 2}\right)$ & 0.0006 & 0.0098 & & & 0.0006 & 0.0097 & & & 0.0004 & 0.0080 & & \\
\hline $\mathrm{P}\left(v_{e}=v_{e 2}, v_{u}=v_{u 2}\right)$ & 0.2109 & 0.0114 & & & 0.2111 & 0.0114 & & & 0.1577 & 0.0092 & & \\
\hline \# observations & & 118 & 842 & & & & 842 & & & & 842 & \\
\hline
\end{tabular}




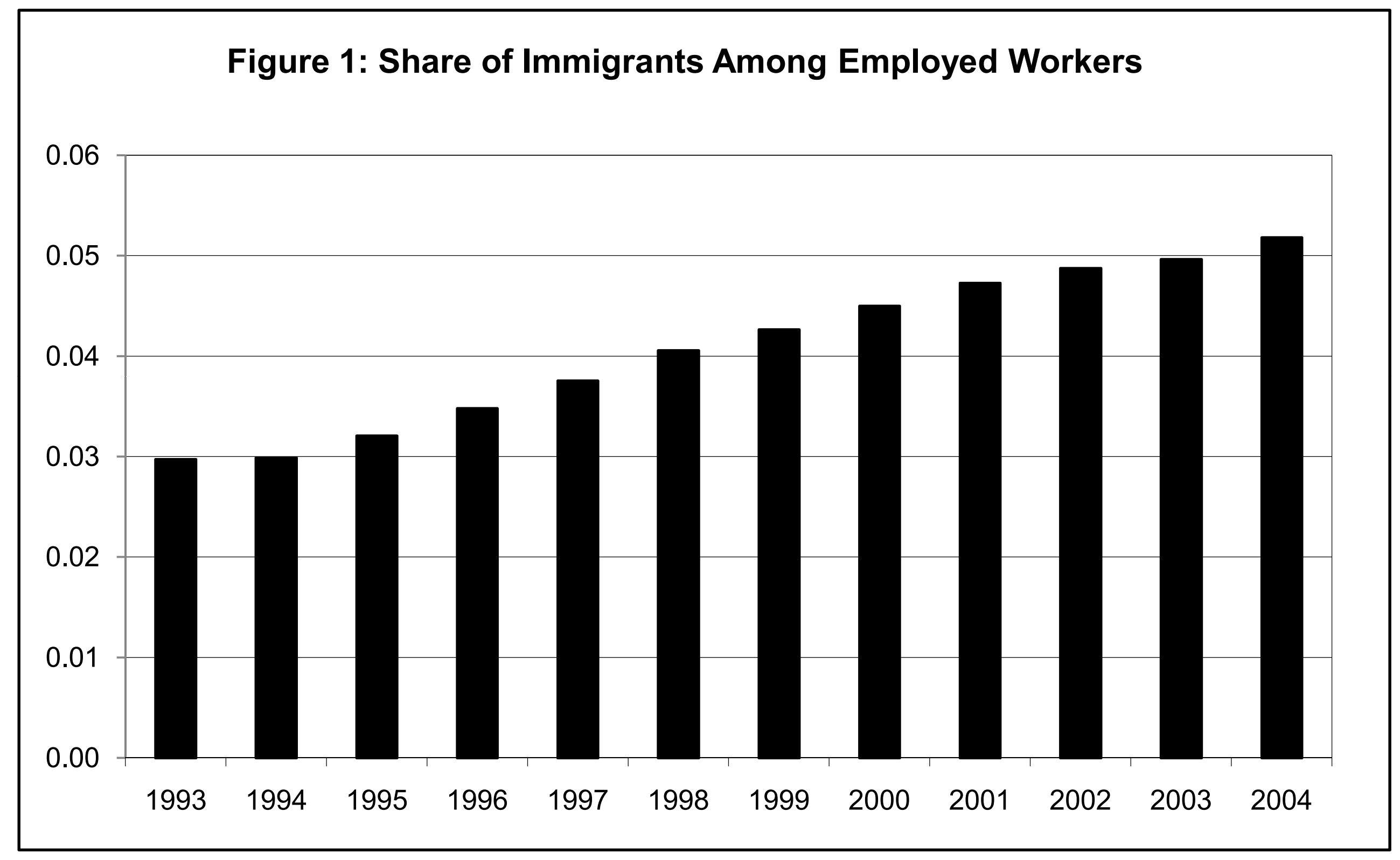

